\title{
THE EFFECTS OF POLITICAL EVENTS AGAINST ABNORMAL RETURN AND TOTAL VOLUME SHARIA SHARES ACTIVITY THAT LISTED IN JAKARTA ISLAMIC INDEX (JII)
}

\author{
Rizka Zulfikar *) \\ Prihatini Ade Mayvita **)
}

\begin{abstract}
This research is an event study that aims to discover whether there is any empirical evidence of the stock changed to one of the political events in Indonesia. This research used a political event namely Jakarta Governor Election 2017 Round II, by using indicator value of abnormal return and Trading Volume Activity Sharia stocks in Jakarta Islamic Index Stock Market. This political event was held on April 19, 2017. Population and sample in this research are 30 sharia stocks in JII. The data used in this research are secondary data consists of daily stock prices, daily share trading volume, and daily stock prices index during the five days before, one day at the time of, and five days after the event. Statistical tool used to test the hypothesis is t test and Wilcoxon Signed Rank Test. $T$ test calculation results indicate that there are significant positive value of abnormal return at a few days around the event date, which means the market responds to this event as a good news. While the results of Wilcoxon Signed Rank Test prove that there are significant differences between the average abnormal return in the period before the time the event and in the period after the time event, but not significant in the period before- after the event. The results of Wilcoxon Signed Rank Test also shows that there are significant differences between the average trading volume activity in the period at the time of-after the event, but not significant in the period before-at the time event and before-after the event.
\end{abstract}

Keywords: Sharia Stock Exchange, Event Studies, Sharia Shares, Abnormal Return, Trading Volume Activity

\section{INTRODUCTION}

\subsection{Research Background}

The movement of economic sector in a country generally can not be separated from the political dynamics that occur in the country. Similarly in Indonesia, political events can cause changes in some components of the economy like the capital market and the stock exchange (Samsul, 2015). Many political events tend to get a response from market participants. This is because these political events can have a positive or negative impact on the conducive climate stability in which investors want to perform transactions in the capital market. Political stability, followed by stability in economic conditions, will make investors feel safe to invest in capital market and stock exchange (Widoatmodjo, 2009).

One of the most significant political events in recent years was the event of DKI Jakarta's Regional Head Election at 2017 which attracts the attention of market participants, considering that Jakarta is the capital of the country as well as the hub of the economic activity in Indonesia. Almost all TVs and media stations, both online and offline continually informed important developments and events during the 2017 election campaign. The emergence of new candidate pairs namely Agus Yudhoyono - Sylviana Murni and Anies Baswedan - Sandiaga Uno made the competition condition among candidates became more stringent and Basuki Tjahja Purnama - Djarot Saiful Hidayat as petahana gave their best political promotions throughout the Campaign.

New leader emerging possibility made market participants put their special expectations on Jakarta's economic progress at the hands of the new leaders. If the new leaders can bring positive changes to the Jakarta's economy through innovative strategies, policies and breakthroughs, so it is possible that positive changes can also contribute to the improvement of the Indonesian economy, 
because the development of economic activity in Jakarta can be regarded as a benchmark measure or barometer for the economy of other regions in Indonesia.

The market reaction against information to reach a new equilibrium price is important. Rapid and accurate market reaction to achieve a new equilibrium price that fully reflects the available information, such market conditions are called efficient markets (Jogiyanto, 2015).

The concept of efficient capital markets has become an interesting topic to be examined because it is a basic concept that can help in understanding how exactly the actual price mechanisms that occur in the market. In financial sector, efficient market concept is more emphasized on information aspect. The relationship between the securities price and information is the key to measure efficient markets (Jogiyanto, 2015). According to Samsul (2015) the information that may affect stock prices are as follows; cash dividend announcement, split announcement, right issue announcement, announcement of share/stock bonus or share/stock dividend, warning announcement, merger and acquisition plan, conflict of interest transaction plan, macro and micro macro variable change, international political event, DJIA stock index movement, Nikkei 225 , Hang Seng., National political events, January effect, Insider information, Changes in economic cycle through leading indicator.

Research on the effect of an event on trading activity is performed through event study. According to Jogiyanto (2015) event study is a study which is studying market reaction to an event whose information is published as an announcement such as financial report, annual report, stock announcement, international financial information, government regulation, political event, legal events, social events and so on that can affect the national economy.

Several previous studies have shown the influence of political events on the stock market in Indonesia, as Rahayu's (2007) research which examined the capital market reaction to the reshuffle event of United Indonesia Cabinet in 2005 and proved that the market reacted positively to the events, positive and significant abnormal return around the date of the cabinet reshuffle announcement.

Similarly to the results of research conducted by Nurhaeni (2009) which shown that the 2009 legislative election events affect the changes in Indonesia Stock Exchange (IDX) when viewed from the side of trading activity. In other words, the Indonesian capital market reacts to the 2009 legislative election which is seen from the difference in average abnormal return and the average trading volume activity before and after the 2009 legislative election.

However, the research conducted by Luhur (2010) stated different things, the result of the research shown that there is no difference of average abnormal return significantly before and after the presidential and vice presidential election on July 8, 2009 on LQ-45 shares listed on BEI. Similarly, the average trading volume activity (TVA) did not produce significant results before and after the presidential and vice presidential elections on 8 July 2009 on LQ-45 shares listed on the IDX.

Jakarta Islamic Index (JII) it self is a stock index made based on Islamic sharia and was launched on July 3, 2000. JII is the result of cooperation between Indonesia Stock Exchange and Danareksa Investment Management (DIM). The basic day used is January 2, 1995 with an index value of 100. JII consists of 30 shares selected from Sharia-compliant stocks and evaluated every 6 months (Indonesia Stock Exchange, 2016). JII index is expected to be a benchmark for the performance of Sharia-based stocks and to further develop the syariah capital market. Sharia stocks included in the JII index are selected shares that have high liquidity and market capitalization so as to illustrate the general reaction of sharia capital markets.

\subsection{Research Problem}

1. Is there an average abnormal return of positive Sharia shares around the date of DKI Jakarta's Regional Head Election at 2017 round II? 
2. Is there a significant difference between the average abnormal return and the total volume of activity of sharia shares in the period before, during the event of DKI Jakarta's Regional Head Election at 2017 round II and thereafter?

\subsection{Research Purpose}

This study is an try to determine the effect of an event on an economic activity which consist of an abnormal return and total volume sharia shares during DKI Jakarta Regional Head Election 2017.

\section{THEORETICAL FRAMEWORK AND HYPHOTESIS DEVELOPMENT}

\subsection{Theoretical Framework}

\subsubsection{Abnormal Return}

Abnormal return is the margin between actual rate of return that occurs with rate of return expected by the investor. The existence of an abnormal return indicates that an announcement or event has an information content (Jogiyanto, 2015). Cornell and Landsman (1989) in Qiu (2014) look at how earnings surprises and earnings forecast changes can impact abnormal return. Abnormal return used to measure the market reaction on information content announcement. When an announcement results abnormal return for investor means the announcement has a right information otherwise announcement who does not produce abnormal return means announcement it has no information content (Simanjutak, 2017)

\subsubsection{Trading Volume Activity}

Trading volume activity (TVA) shows stock trading activity and reflects how active and liquid a stock is traded in the stock market. TVA calculation is done by comparing the number of shares of the company being traded with the total number of shares/stocks beredar (sprading/circulating) among companies during the study period (Yusuf et al 2009).

\subsection{Hyphotesis}

$\mathrm{H}_{1}$ : There is a significant positive reaction of Sharia shares around event of DKI Jakarta's Regional Head Election at 2017 round II.

$\mathrm{H}_{2}$ : The average value of abnormal return of sharia shares before and during event of DKI Jakarta's Regional Head Election at 2017 round II has a significant difference.

$\mathrm{H}_{3}$ : The average value of abnormal return after and during event of DKI Jakarta's Regional Head Election at 2017 round II has a significant difference.

$\mathrm{H}_{4}$ : The average value of abnormal return before and after event of DKI Jakarta's Regional Head Election at 2017 round II has a significant difference.

$\mathrm{H}_{5}$ : The average value of TVA before and during event of DKI Jakarta's Regional Head Election at 2017 round II has a significant difference.

$\mathrm{H}_{6}$ : The average value of TVA before and after the elections of event of DKI Jakarta's Regional Head Election at 2017 round II has a significant difference.

$\mathrm{H}_{7}$ : The average value of abnormal return before and after event of DKI Jakarta's Regional Head Election at 2017 round II has a significant difference.

\section{RESEARCH METHOD}

\subsection{Research Design}

Model used in this study is a market-adjusted model. Market adjusted model is not necessarily use estimation periods to form its estimation models (Jogiyanto, 2015). In this research, the observation period used is 11 days of stock that consists of : (a) 5 days of stock before event of DKI Jakarta's Regional Head Election at 2017 round II on April 19, 2017; (b) 1 day event (event date); (c) 5 trading days after before the 2017 Second Regional Head election of 2017 on April 19, 2017. The analytical method used in this research/study is quantitative analysis with compare means sample $\mathrm{t}$ test paired which running by SPSS 23 in testing homogeneity and normality. 
Homogeneous and normal distributed data were tested with one side $t$ test and paired sample t test while non homogeneous and non normal distributed data were then tested by non parametric method using Kolmogrov-Smirnov test and Wilcoxon Signed Rank Test.

\subsection{Population and Sample}

In this research, researcher are uses all population or 30 sharia stocks as their research object. List of 30 shares/stocks included in the calculation of Jakarta Islamic Index (JII) for the period of December 2016 - May 2017 at Indonesia Stock Exchange (IDX) in accordance with the announcement of Indonesia Stock Exchange No: Peng-00917/ BEI.OPP/11-2016 dated November 29, 2016 are as follows :

Table 1 List of Sharia Stock at JII

\begin{tabular}{|c|c|l|c|c|l|}
\hline No & Code & \multicolumn{1}{|c|}{ Company } & No & Code & \multicolumn{1}{|c|}{ Company } \\
\hline 1 & AALI & Astra Agro Lestari Tbk & 16 & MIKA & Mitra Keluarga Karyasehat Tbk \\
\hline 2 & ADHI & Adhi Karya (Persero) Tbk & 17 & MYRX & Hanson Intenational Tbk \\
\hline 3 & ADRO & Adaro Energy Tbk & 18 & PGAS & $\begin{array}{l}\text { Perusahaan Gas Negara (Persero) } \\
\text { Tbk }\end{array}$ \\
\hline 4 & AKRA & AKR Corporindo Tbk & 19 & PTBA & $\begin{array}{l}\text { Tambang Batubara Bukit Asam } \\
\text { (Persero) Tbk }\end{array}$ \\
\hline 5 & ANTM & Aneka Tambang (Persero) Tbk & 20 & PTPP & PP (Persero) Tbk \\
\hline 6 & ASII & Astra International Tbk & 21 & PWON & Pakuwon Jati Tbk \\
\hline 7 & BSDE & Bumi Serpong Damai Tbk & 22 & SILO & Siloam International Hospitals Tbk \\
\hline 8 & ICBP & $\begin{array}{l}\text { Indofood CBP Sukses Makmur } \\
\text { Tbk }\end{array}$ & 23 & SMGR & Semen Indonesia (Persero) Tbk \\
\hline 9 & INCO & Vale Indonesia Tbk & 24 & SMRA & Summarecon Agung Tbk \\
\hline 10 & INDF & Indofood Sukses Makmur Tbk & 25 & SSMS & Sawit Sumbermas Sarana Tbk \\
\hline 11 & INTP & $\begin{array}{l}\text { Indocement Tunggal Prakarsa } \\
\text { Tbk }\end{array}$ & 26 & TLKM & $\begin{array}{l}\text { Telekomunikasi Indonesia (Persero) } \\
\text { Tbk }\end{array}$ \\
\hline 12 & KLBF & Kalbe Farma Tbk & 27 & UNTR & United Tractors Tbk \\
\hline 13 & LPKR & Lippo Karawaci Tbk & 28 & UNVR & Unilever Indonesia Tbk \\
\hline 14 & LPPF & $\begin{array}{l}\text { Matahari Department Store } \\
\text { Tbk }\end{array}$ & 29 & WIKA & Wijaya Karya (Persero) Tbk \\
\hline 15 & LSIP & $\begin{array}{l}\text { PP London Sumatra Indonesia } \\
\text { Tbk }\end{array}$ & 30 & WSKT & Waskita Karya (Persero) Tbk \\
\hline
\end{tabular}

Source : IDX (2016)

\subsection{Research Variables}

\subsubsection{Rate of Return of Individual Stock $\left(R_{i t}\right)$}

$$
R_{i t}=\frac{P_{i t}-P_{i t-1}}{P_{i t-1}}
$$

\subsubsection{Rate of Return Market $\left(\boldsymbol{R}_{m, t}\right)$}

$R_{m, t}=\frac{J I I_{t}-J I I_{t-1}}{J I I_{t-1}}$

\subsubsection{Expected Return}

$$
E\left(R_{i t}\right)=R_{m, t}
$$




\subsubsection{Abnormal Return}

$A R_{i t}=R_{i t}-E\left(R_{i t}\right)$

\subsubsection{Average Abnormal Return}

$\mathrm{AAR}=\frac{1}{n} \sum_{i=t}^{n} E\left(R_{i t}\right)$

\subsubsection{Trading Volume Activity}

$T V A_{i, t}=\frac{\text { Numberofsharesoffirmitradedintimet }}{\text { Numberofsharesoffirmiouttandedintimet }}$

\subsubsection{Average Trading Volume Activity}

$\bar{X}_{T V A}=\frac{\sum_{i=1}^{n} T V A_{i}}{n}$

\subsection{Research Framework}

The research framework used is as follows:

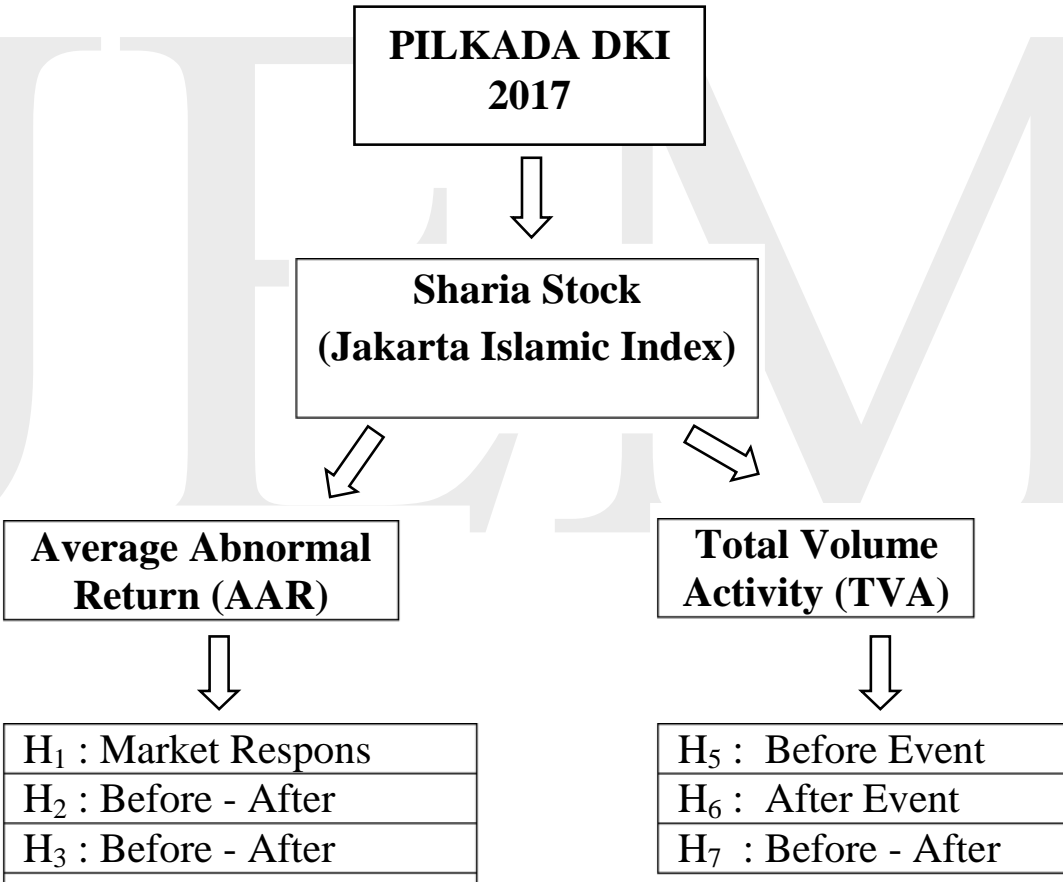

Picture 1 Research Framework

\subsection{Type of Data}

The type of data used in this study is secondary data in the form of time series data in the form of daily stock transactions, the volume of shares traded and the volume of shares outstanding. The data for this research are obtained from various sources including IDX, Yahoo Finance and Google Finance, and JII. 


\section{Research Periods}

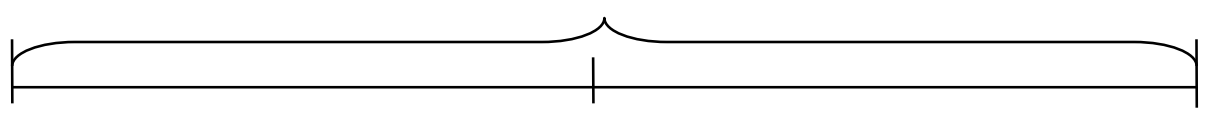

t-5

t0 $\mathrm{t}+5$

(19 Apr'17)

Picture 2 Research Periods

\section{RESEARCH RESULT AND ANALYSIS}

\subsection{Normality and Homogienity Testing}

Normality and homogeneity test shows that the distribution of data is not normal and not homogeneous which means the difference test will be done with Wilcoxon Signed Rank Test Test (Sig. > 0.05). The results of normality and homogeneity test can be seen in table 2 below.

Table 2 Normality and Homogienity Testing

\begin{tabular}{|l|c|c|c|}
\hline Data & Normality Test (Sig) & Homogienity Test (Sig) & Decision \\
\hline AAR & 0.037 & 0.001 & Abnormal, Inhomogeneous \\
\hline TVA & 0.001 & 0.000 & Abnormal, Inhomogeneous \\
\hline
\end{tabular}

Source : Output SPSS (2017)

\subsection{Descriptive Analysis and Hypothesis Testing}

\subsubsection{Descriptive Analysis}

Table 3 AAR

\begin{tabular}{|l|l|l|}
\hline Period & AAR & Standard Deviation \\
\hline Before & -0.001183 & 0.021 \\
\hline During & -0.004839 & 0.009 \\
\hline After & 0.002045 & 0.004 \\
\hline
\end{tabular}

Source : Output SPSS (2017)

Based on the above table, it can be seen that the AAR stock during the period before and during event of DKI Jakarta's Regional Head Election at 2017 round II is negative and during the period after event the average abnormal return is positive. Daily stock AAR calculation during the study period can be seen in Table 4 below:

The daily AAR stock calculation results during the study period indicate that the AAR value is mostly positive. Negative AAR only occurs three times which are at $t-1, t)$ and $t+5$. The highest AAR value occurs in the period of three days after the occurrence of $(t+3)$ that is 0.0095 , while the lowest AAR value occurs at $t 0$ that is equal to -0.0067 . 
Table 4 The Daily AAR Stock Calculation

\begin{tabular}{|l|l|c|}
\hline Period & Average AAR & Standard Deviation \\
\hline$t-5$ & 0.003954 & 0.015 \\
\hline$t-4$ & 0.001745 & 0.020 \\
\hline$t-3$ & 0.002133 & 0.002 \\
\hline$t-2$ & 0.003404 & 0.017 \\
\hline$t-1$ & -0.017149 & 0.026 \\
\hline$t \quad 0$ & -0.004839 & 0.009 \\
\hline$t+1$ & 0.001822 & 0.013 \\
\hline$t+2$ & 0.004763 & 0.017 \\
\hline$t+3$ & 0.009520 & 0.032 \\
\hline$t+4$ & 0.000908 & 0.017 \\
\hline$t+5$ & -0.006785 & 0.021 \\
\hline
\end{tabular}

Source : Secondary Data Processed (2017)

Table 5 ATVA per Period

\begin{tabular}{|l|l|c|}
\hline Period & Average TVA & Standard Deviation \\
\hline Before & 0.001962 & 0.004 \\
\hline D-Day & 0.001929 & 0.003 \\
\hline After & 0.002381 & 0.005 \\
\hline
\end{tabular}

Source : Secondary Data Processed (2017)

Based on the above table, it can be seen that the average TVA shares/stocks during the period before had decreased at the time of event of DKI Jakarta's Regional Head Election at 2017 round II and experiencing rebound after the event. The daily calculation of TVA shares/stocks daily during the study period can be seen in Table 6 below:

Table 6 Daily ATVA

\begin{tabular}{|l|l|c|}
\hline Period & Average TVA & Standard Deviation \\
\hline$t-5$ & 0.001892 & 0.003 \\
\hline$t-4$ & 0.002472 & 0.005 \\
\hline$t-3$ & 0.001527 & 0.003 \\
\hline$t-2$ & 0.001849 & 0.003 \\
\hline$t-1$ & 0.002070 & 0.005 \\
\hline$t 0$ & 0.001929 & 0.003 \\
\hline$t+1$ & 0.001776 & 0.005 \\
\hline$t+2$ & 0.002524 & 0.005 \\
\hline$t+3$ & 0.003078 & 0.005 \\
\hline$t+4$ & 0.002433 & 0.005 \\
\hline$t+5$ & 0.002095 & 0.004 \\
\hline
\end{tabular}

Source : Secondary Data Processed (2017)

Based on the data, it can be seen that the movement of TVA values during the 11 day period of events is quite volatile. In periods of $\mathrm{t}-3, \mathrm{t}-2$ and $\mathrm{t}-1$, TVA values tend to increase but decrease again at 0 at the 0.001929 level. while in the period after the event, in the period $t$ of $+1, t+2$ and $t$ +3 , TVA values tend to increase and reach the highest value at the level of 0.003078 , then decrease again at $t+4$ and $t+5$ at the level of 0.002095 . 


\subsection{2 $\mathrm{H}_{1}$ Testing}

Table $7 \mathrm{H}_{1}$ Testing

\begin{tabular}{|c|c|c|c|}
\hline Periods & AAR & p-value & Decision \\
\hline $\mathrm{t}-5$ & 0.003954 & 0.002 & Rejected H0*) \\
\hline $\mathrm{t}-4$ & 0.001745 & 0.014 & Approved H0 \\
\hline$t-3$ & 0.002133 & 0.009 & Rejected H0*) \\
\hline $\mathrm{t}-2$ & 0.003404 & 0.002 & Rejected H0*) \\
\hline $\mathrm{t}-1$ & -0.017149 & 0.022 & Rejected H0*) \\
\hline t 0 & -0.004839 & 0.003 & Approved H0 \\
\hline$t+1$ & 0.001822 & 0.052 & Approved H0 \\
\hline$t+2$ & 0.004763 & 0.008 & Rejected H0*) \\
\hline$t+3$ & 0.009520 & 0.002 & Rejected H0*) \\
\hline$t+4$ & 0.000908 & 0.021 & Rejected H0*) \\
\hline$t+5$ & 0.003954 & 0.009 & Rejected $\mathrm{H} 0 *$ ) \\
\hline
\end{tabular}

Source : Secondary Data Processed (2017)

Hypothesis 1 was tested by $t$ test and the following table 5 presents the results of $t$ test one sample for 11 days of the event period. The basis of the conclusion is that if the p-value value of the test statistic $\mathrm{t}<0.05$, then the hypothesis is rejected. From Table 5 it can be explained that there is a significant positive abnormal return on the period of $\mathrm{t}-5, \mathrm{t}-3, \mathrm{t}-2, \mathrm{t}+2, \mathrm{t}+3, \mathrm{t}+4$ and $\mathrm{t}+5$. While the average abnormal return is negative significant in period of $\mathrm{t}-1$. Thus, $\mathrm{H} 1$ is accepted so it can be concluded that the emergence of AAR which has a significant positive value around the date of the event shows that event of DKI Jakarta's Regional Head Election at 2017 round II has information content that is responded as good news by market. While the emergence of AAR is significant during the event of DKI Jakarta's Regional Head Election at 2017 round II which assessed to have information content that responded as bad news by market.

\subsection{3 $\mathrm{H}_{2}, \mathrm{H}_{3}, \mathrm{H}_{4}$ Testing}

Table $8 \mathrm{H}_{2}, \mathrm{H}_{3}, \mathrm{H}_{4}$ Testing

\begin{tabular}{|l|l|l|l|}
\hline Periods & AAR & p-value & Decision \\
\hline $\mathrm{t}-5$ & 0.003954 & 0.002 & Rejected $\left.\mathrm{H} 0^{*}\right)$ \\
\hline $\mathrm{t}-4$ & 0.001745 & 0.014 & Approved H0 \\
\hline $\mathrm{t}-3$ & 0.002133 & 0.009 & Rejected $\left.\mathrm{H} 0^{*}\right)$ \\
\hline $\mathrm{t}-2$ & 0.003404 & 0.002 & Rejected $\left.\mathrm{H} 0^{*}\right)$ \\
\hline $\mathrm{t}-1$ & -0.017149 & 0.022 & Rejected H0*) \\
\hline $\mathrm{t} 0$ & -0.004839 & 0.003 & Approved H0 \\
\hline $\mathrm{t}+1$ & 0.001822 & 0.052 & Approved H0 \\
\hline $\mathrm{t}+2$ & 0.004763 & 0.008 & Rejected $\left.\mathrm{H} 0^{*}\right)$ \\
\hline $\mathrm{t}+3$ & 0.009520 & 0.002 & Rejected $\left.\mathrm{H} 0^{*}\right)$ \\
\hline $\mathrm{t}+4$ & 0.000908 & 0.021 & Rejected $\left.\mathrm{H} 0^{*}\right)$ \\
\hline $\mathrm{t}+5$ & 0.003954 & 0.009 & Rejected $\left.\mathrm{H} 0^{*}\right)$ \\
\hline
\end{tabular}

Source : Secondary Data Processed (2017)

Testing of hypothesis is done by comparing the AAR 5 days before and during Election of DKI 2017 Round II ( $\mathrm{H}_{2}$ Test), during the event and after the event $\left(\mathrm{H}_{3}\right.$ Test) and comparing before event and after event $\left(\mathrm{H}_{4}\right.$ Test). To see the significance of AAR differences between the study periods, wilcoxo test was conducted because the data is not normally distributed and not homogeneous. The basis of the conclusion is that if the p-value of the wilcoxon test statistic $<0.05$, then the hypothesis is rejected. Wilcoxon signed ratings test results against AAR are shown in Table 8 below: 
Table $9 \mathrm{H}_{2}, \mathrm{H}_{3}, \mathrm{H}_{4}$ Testing

\begin{tabular}{|c|l|l|l|}
\hline Hypothesis & Variable & p-value & Decision \\
\hline 2 & Before & 0.027 & Rejected H0 \\
\hline 3 & D Day & 0.079 & Accepted H0 \\
\hline 4 & After & 0.178 & Accepted H0 \\
\hline
\end{tabular}

Source : Secondary Data Processed (2017)

There are significant differences in share/stock of AARs in the period before and during the event of DKI Jakarta's Regional Head Election at 2017 round II which is shown by p-value $(0.0027$ $<0.005)$. However there is no significant AAR difference for the period after the event and the period before - after the event.

\subsection{3 $\mathrm{H}_{5}, \mathrm{H}_{6}, \mathrm{H}_{7}$ Testing}

Testing against the hypothesis was performed by comparing TVA 5 days before and during the event of DKI Jakarta's Regional Head Election at 2017 round II ( $\mathrm{H}_{5}$ Test), during the event and after the event $\left(\right.$ Test $\left.\mathrm{H}_{6}\right)$ and compare before event and after event $\left(\right.$ Test $\left.\mathrm{H}_{7}\right)$. To see the significance of TVA differences between the study periods, Wilcoxon Signed Rank Test was done as the data were not normally distributed and not homogeneous. When the p-value value of Wilcoxon Signed Rank test statistic $<0.05$, then the hypothesis is rejected. Wilcoxon Signed Rank Test results on TVA are shown in Table 9 below:

Table $10 \mathrm{H}_{5}, \mathrm{H}_{6}, \mathrm{H}_{7}$ Testing (Wilcoxon Signed Rank Test Results on TVA)

\begin{tabular}{|c|l|l|l|}
\hline Hypothesis & Variable & p-value & Decision \\
\hline 5 & Before & 0.992 & Accepted H0 \\
\hline 6 & D Day & 0.009 & Rejected H0 \\
\hline 7 & After & 0.758 & Accepted H0 \\
\hline
\end{tabular}

Source : Secondary Data Processed (2017)

There is a significant difference of TVA shares in the period after and during the event of DKI Jakarta's Regional Head Election at 2017 round II which is shown with p-value $(0.009<0.05)$. However, there were no significant TVA differences for the post-event period and for the pre-event period.

\subsection{Research Discussion}

On t-1 case, AAR is negative significant, this indicates that the period 1 day before the event of DKI Jakarta's Regional Head Election at 2017 round II responded negatively by market participants. So that stock prices on the floor of the stock declined so that there is a tendency of investors to behave negatively because of worried about political changes. Significant positive responses began to appear several days after the event on $t+2, t+3, t+4$ and $t+5$ because at that time some institutions have given results through the quick count, where the pairs of Anis Baswedan Sandiaga Uno was superior to the pair of Basuki Tjahja Purnama - Saiful Djarotand also because the smooth and orderly running of elections leading to a controlled political and security situation to make market participants respond positively a few days after the event. However, in general it can be concluded that investors respond positively to this event, marked by the abnormal return that has a significant positive at $\mathrm{t}-1, \mathrm{t}+2, \mathrm{t}+3, \mathrm{t}+4$ and $\mathrm{t}+5$. So it can be said that the market participants welcomed the event of DKI Jakarta's Regional Head Election at 2017 Round II and also welcomed the victory of Anies Baswedan - Sandiaga Uno, although the victory was still temporary because it was based on the quick count (quick count). Market participants seem optimistic that the election of Anis-Sandiaga Uno as the new governor for the next 5 years will be able to bring new changes, especially in the economic sector in Jakarta which is actually the capital city of Indonesian. 
There are significant differences in the average abnormal return of $\mathrm{H}_{2}$ hypothesis testing results in the period before the moment of events. In the period before the event, which was $\mathrm{t}-4$, investors tend to be wait and see because of the uncertainty of political information in circulation. Investors are faced with various informations from political experts, television media, and print media, where the information is different from one another, so that during the movement of abnormal return was still quite stable.

The result of hypothesis testing of $\mathrm{H}_{3}$ in the period after the occurrence of the event did not show any significant difference in AAR shares/stocks. This happens because average value of abnormal return is negatively low at time of t0, while the abnormal return in the period after the event tends to be dominated by a positive value.

Hypothesis 4 test results in the period before and after the event proves that there is no difference in average abnormal return of stock. This proves that there is no significant difference between AAR share/stock in the period before and after the event of DKI Jakarta's Regional Head Election at 2017 Round II. These results indicate that market reaction to political events viewed from the abnormal return of stock, tends to be momentary and not prolonged.

The results of hypothesis testing of 5,6 and 7 indicate that there is no significant difference between TVA before and during the event, as well as on the events and after the event of DKI Jakarta's Regional Head Election at 2017 Round II. Significant TVA differences occured precisely in the periods before and after the event. The difference in the average of trading volume activity during the period of observation before and after the event shows an increase of demand, it can be interpreted that the event of DKI Jakarta's Regional Head Election at 2017 Round II is considered as positive information, so that investors will buy shares in their expectation will get an abnormal return.

The results of this study also indicate that the response of investors toward the stock market is so appreciative in the event of DKI Jakarta's Regional Head Election at 2017 and the capital market analysts have predicted before following the announcement elections results that put the couple of Anis Baswedan - Sandiaga Uno as the elected governor.

\section{RESEARCH CONCLUSION, LIMITATION, AND RECOMMENDATION}

\subsection{Conclusion}

Based on the analysis of research results described above, it can be concluded that:

1. Sharia stocks in JII responded to information from the event of DKI Jakarta's Regional Head Election at 2017 Round II as good news indicated by the emergence of significant positive reactions in period $\mathrm{t}-4, \mathrm{t}-2, \mathrm{t}+1, \mathrm{t}+2$, and $\mathrm{t}+5$. While, negative reaction is only significant in period of $t 0$ or during the event of DKI Jakarta's Regional Head Election at 2017 Round II.

2. There is no significant difference in AAR in the period of after - during - before the event of DKI Jakarta's Regional Head Election at 2017 Round II. A significant difference of AAR occurred in the period before and during the event of DKI Jakarta's Regional Head Election at 2017 Round II.

3. There is no average difference in TVA significantly before and after the event of DKI Jakarta's Regional Head Election at 2017 Round II on sharia stocks registered in JII. Significant average difference in TVA was found in TVA after and during the event of DKI Jakarta's Regional Head Election at 2017 Round II on the sharia stocks registered at JII.

4. The rise of political stability and market players' confidence in new leader who will lead DKI for the next 5 years give positive response to sharia stocks registered in JII.

\subsection{Limitation}

The use of Jakarta PILKADA round II 2017 cases as the research object need to be enlarged not only in specifics political event but also in social cultural issues (religion sentiment) and racial issues. 


\subsection{Recommendation}

The following are some suggestions that can be considered for the next research:

1. This research uses two indicators of market reaction measurement, which are abnormal return and stock trading volume activity. Therefore, for the next research it is suggested to develop other market reaction measurement indicator besides using the two main variables, such as the frequency of stock trading and stock bid-ask spread to enrich the results of the research

2. Capital market participants should keep a close look at non-economic information such as political events that can affect the markets.

3. Information occurs in the stock exchange is not all valuable information, as a result, capital market participants must precisely sort out and analyze only relevant information for consideration in decision-making, so that investors are not in a hurry to sell and more rational in decision-making.

4. The object of research in this study is Sharia stocks on the JII exchanges for the period of December 2016 - May 2017. Further research is expected to take all stocks listed on the Stock Exchange as their object of research.

\section{REFERENCES}

Hartono, J. (2008). Teori Portofolio dan Analisis Investasi, Edisi 5. Yogyakarta : Penerbit BPFE.

Jogiyanto. (2015). Teori Portofolio dan AnalisisInvestasi, Edisi 10. Yogyakarta : Penerbit BPFE.

Luhur, S. (2010). Reaksi Pasar Modal Indonesia Seputar Pemilihan Umum 8 Juli 2009 pada Saham LQ45. Jurnal Keuangan dan Perbankan 14 (2) : 249 - 262.

Nurhaeni, N. (2009). Dampak Pemilihan Umum Legislatif Indonesia Tahun 2009 Terhadap Abnormal Return Dan Aktivitas Volume Perdagangan Saham Di BEI. Tesis. Program Pasca Sarjana Manajemen. Semarang : Universitas Diponegoro.

Qiu, Luke. (2014). Earnings Announcement and Abnormal Return of S\&P 500 Companies. Honors Thesis, Economics Department, Washington University accessed from https://economics.wustl.edu/files/economics/imce/luke_qiu_-_final.pdf

Rahayu, C, Wahyu E. (2007). Reaksi Pasar Modal Terhadap Pengumuman Perombakan (Reshuffle) Terbatas Kabinet Indonesia Bersatu (Studi Empiris pada Perusahaan-Perusahaan yang Terdaftar di Bursa Efek Jakarta). Jurnal Sinergi 9 (2) : 129-142.

Samsul, M. (2015). Pasar Modal dan Manajemen Portofolio, Edisi 2. Jakarta : Penerbit Erlangga.

Simanjutak, Suhermanto. (2017). Analisis Perbandingan Average Abnormal Return dan Average Trading Volume Activity Sebelum dan Sesudah Peristiwa Pilkada DKI Jakarta Tahun 2017 (Studi Empiris pada Perusahaan Anggota Indeks LQ45 di Bursa Efek Indonesia). Departments of Economics and Business, Lampung University. Accessed from http://digilib.unila.ac.id/28327/3/3.\%20SKRIPSI\%20FULL\%20TANPA\%20BAB\%20PEMB AHASAN.pdf

Yusuf, S. D, Atim, D. and Harry S. (2009). Analisis Reaksi Investor Terhadap Pengumuman Right Issue di Bursa Efek Jakarta. WACANA 12 (4) : 792-814.

Widoatmodjo, S. (2009). Pasar Modal Indonesia: Pengantar dan Studi Kasus. Yogyakarta : Penerbit Ghalia Indonesia. 
Jurnal Ilmiah Bidang Akuntansi dan Manajemen (JEMA) Vol. 14 No. 2 (2017)

http://riset.unisma.ac.id/index.php/jema

http://www.idx.co.id/

http://www.finance.yahoo.co.id/

http://www.google.co.id/finance/

*) Rizka Zulfikar, University of Islam Kalimantan Muhammad Arsyad Al-Banjary Banjarmasin

**) Prihatini Ade Mayvita, University of Islam Kalimantan Muhammad Arsyad Al-Banjary Banjarmasin 